が得られる。而して $\log 1.25 \doteq 0.22$ だから $\gamma_{2}=-1.5$ と なり分布の式中 $\gamma_{2}=-1.5$ に対応して $\nu=\frac{1}{2}$ を得る。今一 つの仮定として $\alpha$ は一定常数 $\varepsilon_{0}$ に收斂するものとすれ ばその分布型式は $y=y_{0}\left(1-\frac{x^{2}}{\varepsilon_{0}^{2}}\right)^{-!}$となり単振動の質 点の存在確率に対応する。帮際 $H_{0} \rightarrow 0$ に於て $L \rightarrow 0$ とな り此場合に詨する $H_{0}$ に相当するすのは界点に外ならな い。從つて物質表面に於ける点は一応振動状況を呈する 事を示すが之はよく事実と一致する。この時 $\sigma \rightarrow \infty$ と なるから $\alpha^{2}=-\left(2+\frac{3}{\gamma_{2}}\right) \sigma^{2} \rightarrow \varepsilon_{0}^{2}$ なる仮定は認められ $\varepsilon_{0}$ は其振幅に外ならない。此等の状況を認め逆にcの 正しい值を求めると $c=\log 1.25$ となり從つて $H_{0}$ と $\gamma_{2}$ との一般関係式は

$$
\gamma_{2}=-1.2 \exp \left(-(\log 1.25)\left\{\left(\frac{H_{0}}{h_{0}}\right)^{\frac{1}{4}}-1\right\}\right\} \text {. }
$$

或は $\gamma_{2}$ の絶対値をとつて

$$
h_{0}=H_{0}\left\{\frac{\log 1}{\log \left(1.5 / r_{2}\right)}\right\}=H_{0} \zeta^{4} \ldots \text {...(3) }
$$

よつて之よりその表面が示す粗さの極根 $h_{0}$ を求める事
ができる。

\section{7. 結語}

粗さの極限は一般の粗さの概念からは，又通常の材料 が示す粗さの資料からは求め難い樣に思われる。併しそ れが特殊な状態を示す時期を求めその時の粗さを解析す れは一応計算によつて求められる。その時期としては磨 耗過程に現われる週期的な陵耗量の頻度が最小となる時 を選べはよい。且その特の粗さの $\Sigma l i / L$ 分布はピアンン エ型をとるものであるから其等を相互に調查し正確な資 料を得てその $\Sigma l i / L$ 分布の $\gamma_{2}$ を求め第(3) 式により最度 の面の粗さ $h_{0}$ を求める事ができる。之がマク口の限界 とすれはミクロは(1) 式の係数 $c$ を導く時 $H_{0 \rightarrow 0}$ で現わ れた振動状況を示す近傍即ち $<h_{0}$ の所と考えられる。 佾 $0<H_{0}<h_{0}$ の場合，ミク口の領域の模型化として例 えば一列に並べた球の $\Sigma i / L$ 分有を考えらるのは興味の ある問題である。 (1954.2.17 受理)

\title{
鍍金浴に於けるピット防止の研究（第一報）
}

\author{
高濃度シテン化銅浴に就へで \\ “野田保夫块川融・鏡島正円 円 $^{* *}$
}

\section{Study on the Antipitting Agent for Plating Bath (I)}

For high concetration copper cyanide plating bath

Yasuo Noda, Akira Nakagawa, Masamaru Kagashima ${ }^{* * *}$

There are many methods to take off the pitting on the deposited surface in the high concentration cupper cyanide baths.

One of these methods is to add some kind of surface active agent to the bath in order to decrease the surface tension of the bath, and easily separate the bubble of hydrogen gas from the deppositing surface.

However, for this purpose the surface active agents must have necesarily the following characteristics :

1) Not to decompose at high temparature (ca. $75^{\circ} \mathrm{C}$ ), and at high alkalinity ( $\mathrm{PH} \mathrm{12-13.)}$

*** The Osaka Municipal Industrial Research Institute, Osaka, Japan.
2) Not to salt out in electrolyte of high concentration.

3) Not to decompose by electrolytic oxidation or reduction.

4) To reduce the surface tension of the electrolyte greatly by its addition even in small quantity.

From such point of view, we tested and studied nine surface active agents which are presumed to give good effect in alkaline and concentrated salt solution. The high concentration copper cyanide baths containing varying quantities of these surface active agents were made and satisfactory results were obtained in plating in three baths. 
Conclusions are at follows:

1) Ionic surface active agents and polyalcohol ester type nonionic surface active agents can not be used in high concentration copper cyanide bath.

2) Polyoxyethylens lauryl alcohol ether, Polyoxyethylene sperm alcohol ether, Polyoxyethylene oleyl alcohol ether of relatively high polymerisation degree $(p=20-50)$ and high purity (98\%), decreased pits on the deposited surface without decomposition and salting out.

3) By addition of the agents in small quantity, makes it possible to reduce the surface tension of the bath to $50 \sim 30$ dyne $/ \mathrm{cm}\left(30^{\circ} \mathrm{C}\right)$.

4) However, it is not possible to remove pitlike hollow caused by adheision of insoluble floating salt (copper complex salt) on the deposited surface and this salt must be removed completely by filtration.

\section{I 緒 言}

鍍金面のピットは，鍍金中に陰極面に発生する水素ガ ス気泡が，電解液と陰極面との界面に付着，停滞し，そ の部分の爾後の電着を妨害する為に発生する事は明らか である。このピットの発生を防止するためには，電解液 の表面張力を低下せしめ, 水素ガス気泡の鍍金面よりの 遊離を容易にすればよく，このためには，浴に適当なる 界面活性剤の添玑が有效であると考えられる。

しかし乍ら，高濃度シアン化銅浴は，塩類の濃度が高 く, 且高溫 $\left(70 \sim 80^{\circ} \mathrm{C}\right)$ 高アルカリ性 $(\mathrm{pH} .12 \sim 13)$ 厄 あるため,これに添加する界面活性昘は，単に浴の表面 張力を低下せしめる效力を有するのみならず，塩析，分 解されることがなく，又電解酸化，電解還元をす受け難 いものでなくてはならない。

著者等は上記の見地より各種の界面活性放を高濃度シ アン化銅浴に添加し，そのピット防止の数果に就いて研 究した。

\section{II 實 驗}

1. 界面活性㓝

添加すべき界面活性風は，高濃度シアン化銅浴により 塩析，分解，電解に依る酸化還元を受ける点を考慮し， 比較的これらの影響の少いと予想せられる第 1 表(次頁) に示す界面活性放を特に合成し，使用した。

* 昭和28年12月 3 日, 近畿地方官公立工業研究機関 合同講演会に於て講演

**大阪市立工業研究所
2. 浴の調製

シアン化銅浴の一般的区分に従つて高濃度シアン化銅 浴を調製した。浴組成及び電解條件は第 2 表の如くであ る。

第 2 表 浴組成及び電解條件

\begin{tabular}{|c|c|c|c|}
\hline $\begin{array}{r}\text { シアン化第一銅 } \\
\mathrm{g} / 1\end{array}$ & $\begin{array}{l}\text { 遊離のシアン化 } \\
\text { ナトリウム } \mathrm{g} / 1\end{array}$ & 水酸化カリウム & PH. \\
\hline 119.0 & 19.1 & 20.0 & 12.6 \\
\hline
\end{tabular}

電解條件

溫度 $: 75^{\circ} \mathrm{C}$, 電流密度 $: 2 \mathrm{~A} / \mathrm{dm}^{2}$, 電流濃度 $: 0.2 \mathrm{~A} / 1$

3. 界面活性凧の添加に依る浴の表面張力の変化

第 1 表の各界面活性阂を，第 2 表の浴に累次添加し， 必要なる添加範囲を定めた。第 1 国はトラウべ氏の滴数 計を用い， $30^{\circ} \mathrm{C}$ に於て測定せる浴の表面張力の変化を 示すものである。

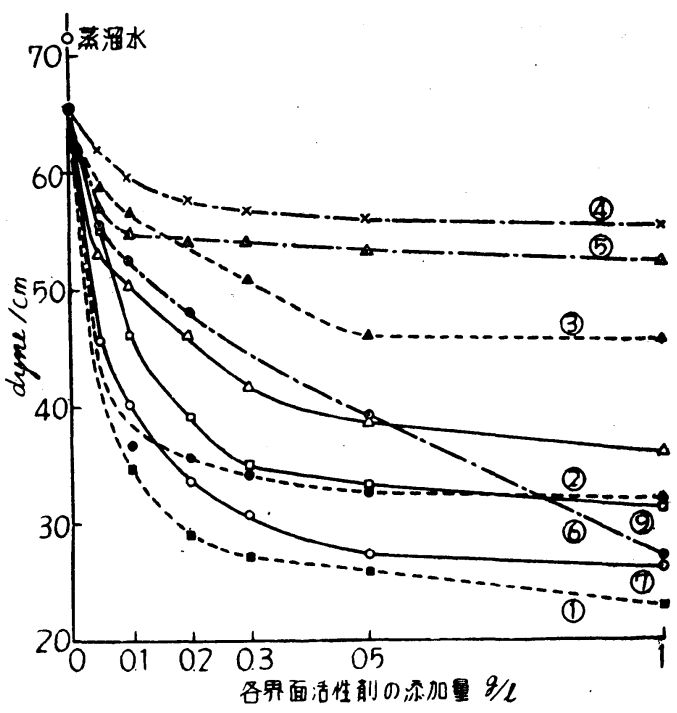

第 1 回 界面活性剂の添加に依る浴の表面力の変化 $\left(30^{\circ} \mathrm{C}\right)$

(1) Sodium alkyl naphthalene sulfonate

(2) Sodium lauryl sulfate

(3) Lauryl pridinium chloride

(4) Polyoxyethylene sorbitan

(5) Polyoxyethylene sorbitan monostearate $(p=12)$ monostearate $(\mathrm{p}=30)$

(6) Polyoxyethylene sorbitan monooleate $(\mathrm{p}=30)$

(7) Polyoxyethylene lauryl alc. ether $(p=30)$

(8) Polyoxyethylene sperm alc. ether $(\mathrm{p}=50)$

(9) Polyoxyethylene oleyl alc. ether $(p=20)$

第1圆に見られる如く，各界面活性凧の添加量が 0.05 $\mathrm{g} / 1 \sim 0.3 \mathrm{~g} / 1$ の範囲に於て急激なる表面張力の下降があ り，更に増量しても，下降の度合は小であつた。故に 
第 1 表 各 種 界面 活 性 剤

\begin{tabular}{|c|c|c|c|c|c|c|c|c|c|}
\hline 界面活性剤 & 1 & 2 & 3 & 4 & 5 & 6 & 7 & 8 & 9 \\
\hline 重 合 $(\mathrm{P})$ & - & - & - & 12 & 30 & 30 & 30 & 50 & 20 \\
\hline${ }_{(\text {外常 溫) }}{ }^{\text {観 }}$ & 黄白色, & 白色粉末 & 夲白色, & 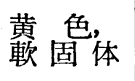 & $\begin{array}{l}\text { 黄色, } \\
\text { 免固体 }\end{array}$ & 黄 色, & $\begin{array}{l}\text { 泉色, } \\
\text { 体田 }\end{array}$ & 泉色, & $\begin{array}{l}\text { 淡黄色, } \\
\text { 䗱 }\end{array}$ \\
\hline 揮 発 分 & 35.5 & 皆 無 & 8.5 & 0.7 & 0.7 & 0.7 & 0.8 & 0.8 & 4 以下 \\
\hline 灰 分 & - & 0.85 & 0.1 & 0.15 & 0.14 & 0.14 & 0.18 & 0.14 & 0.2 \\
\hline 鉄 分 & 0.001 以下 & 皆 無 & 0.001 以下 & 0.001 以下 & 0.001 以下 & 0.001 以下 & 0.001 以下 & 0.001 以下 & 0.001 以下 \\
\hline 未反応物 $\%$ & 0.5 & 無 し & 0.5 & 無 L & 無 し & 無 $し$ & 無 . し. & 無 し & 無 し \\
\hline 無 機 物 & 14.6 & 無 L & - & 0.11 & 0.10 & 0.12 & 0.11 & 0.12 & 0.11 \\
\hline $\begin{array}{l}\text { 水 } \quad \text { 分 } \\
\end{array}$ & 34.6 & - & 6.5 & 1.4 & 1.5 & 1.5 & 1.4 & 1.3 & 1.2 \\
\hline 有效成 分 $\%$ & 50.3 & 100.0 & 85.0 & 98以上 & 98以上 & 98以上 & 98以上 & 98以上 & 98以上 \\
\hline A. V. & - & - & - & 4.5 & 2.5 & 2.2 & 1.2 & 1.1 & 1.2 \\
\hline ОH. V. & - & - & - & 149.5 & 115.5 & 116.4 & 76.9 & 53.7 & 90.0 \\
\hline I. V. & - & - & - & - & - & 8.4 & 一 & 8.6 & 9.6 \\
\hline S. V. & - & - & - & 69.8 & 55.7 & 51.3 & - & - & - \\
\hline 軟 化 点 & - & 一 & 一 & 30.5 & 25.5 & $\begin{array}{l}\text { 液 体 } \\
\text { (常溫) }\end{array}$ & 43.5 & 36.2 & 36.2 \\
\hline 水 溶 性 & $\begin{array}{l}\text { 殆んぞ䅎 } \\
\text { 明に溶解 }\end{array}$ & 透明に & $\begin{array}{l}\text { 殆儿ど透 } \\
\text { 明に溶解 }\end{array}$ & 白 濁 & 盜水に溶 & $\begin{array}{l}\text { 透明に } \\
\text { 溶 解 }\end{array}$ & $\begin{array}{l}\text { 透明に } \\
\text { 溶 } \\
\end{array}$ & 透明に & $\begin{array}{l}\text { 稚意の水 } \\
\text { 溶 } \\
\end{array}$ \\
\hline $\begin{array}{l}\text { 比表面張力 } \\
1 \% \text { 溶液, } 4^{\circ} \mathrm{C}\end{array}$ & 0.4 & 0.38 & 0.51 & 0.47 & 0.48 & 0.47 & 0.47 & 0.53 & 0.5 以下 \\
\hline $1 \%$ 水溶液 & 7 & 7 & 7 & 7 & 7 & 7 & 7 & 7 & 7 \\
\hline $\begin{array}{c}\mathrm{NaOH} \text { 抵抗性 } \\
\mathrm{NaOH} \mathrm{g} / 1 \\
75 \pm 0^{\circ} \mathrm{C}\end{array}$ & 21 & 110 & 1 以下 & 42 & 62 & 105 & 35 & 100 & 36 \\
\hline
\end{tabular}

界面活性剂 1: Sodium alkyl naphthalene sulfonate, 2: Sodium lauryl isulfate, 3: Lauryl piridinium chloride, $4:$ Polyoxyethlene sorbitan monostearate, $5:$ Polyoxyethylene sorbitan monostearate, 6: Polyoxyethylene sorbitan monooleate, $7:$ Polyoxyethylene lauryl alcohol ether, 8: Polyoxyethylene sperm alcohol ether, 9: Polyoxyethylene oleyl alcohol ether

(1)：界面活性剂 $0.5 \mathrm{~g} / 1$ の溶液を， $75 \pm 0^{\circ} \mathrm{C}$ に於て発量せしめる水酸化ナトリウムの最小瓦数である。 
$0.05 \mathrm{~g} / 1 \sim 0.5 \mathrm{~g} / 1$ の範围に於て，各界面活性剤を添加し て鍍金を行つた。

4. 界面活性剂の添加によるピットの防止效果

鍍金試験片は，第 2 圆の如き形状寸法の真鍮板を用い 表面は充分平滑に研察し，且周边部に丸咮を一えた。こ れは各試験片面に不均一に 存在する條痕, 倣唓のため 鍍金面に発生するピットの 数及びその形状が変化し， そのために, 界面活性郕に よる防止效果の判定に韶美 が生じるのを防ぐためであ る。又第 2 圆の如く L字型 に属曲し，液面に対する水 平面，垂直面及び屈曲部の 鍍金状態を同一試料で哂識 出来るようにした。

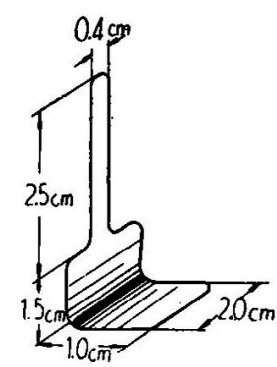

第2 圆鍍金試験片材 料：真鍮板 厚さ： $0.03 \mathrm{~cm}$

各界面活性訪の添加の適否改びピット防止剂としての 效果は第3 表の如くである。

即ち, 番号 1,2 及び 3 のイオン型界面活性剂は, 高濃

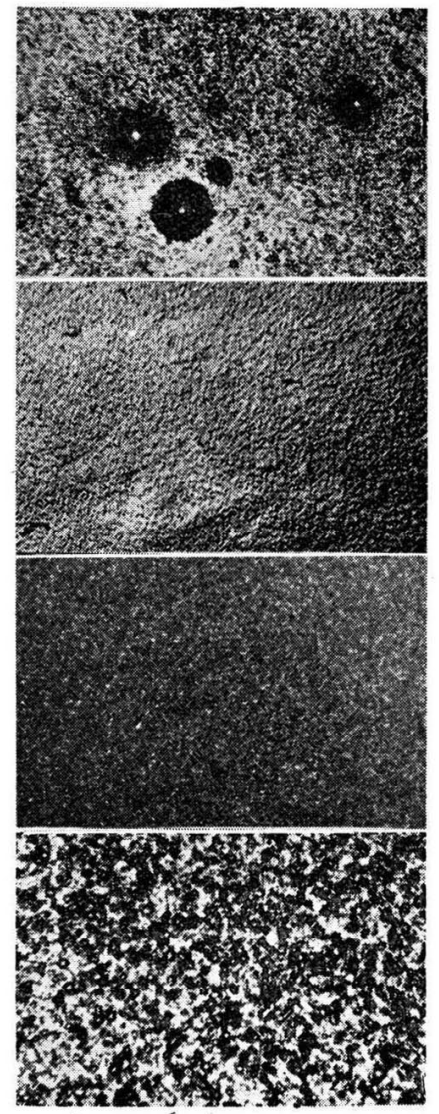

界面活性剂無添加

No. 7 (Polyoxyethylene lauryl alcohol ether) $0.3 \mathrm{~g} / 1$ を添加

No. 8 (Polyoxyethylene sperm alcohol ether) $0.1 \mathrm{~g} / 1$ 添加

No. 9 (Polyoxyethylene oleyl alcohol ether) $0.1 \mathrm{~g} / 1$ を添加
度浴に於て，塩析されて白濁し，又分解して錪金面を不 良にし，ピットは減少せず，䆓ろ増加の傾问にあり，效 果は全く認められなからた。

非イオン型界面活性成中の番号 4,5 及び 6 の多価アル コール・エステル系のすのは塩析ざれ，且奄解に传り分 解するすの今如く，電解時閒と共に，塩析分離する量が 次第に增加した。ピットは幾分減少するが，鉱金面も不 良であり，使用に堪え難い結棵を示した。

番号 7,8 及び9はアルコール・エーテル采のわのであ り, 高濃度浴に於てす塩析分解などの現象はなく，又珵 解による分解もない。又鍍金面の状態も良好であり，ピ ットは殆んど生成しなからた。

アルコール・エーテル系の界面活性放の重合度は, 第 1表の如く比較的高重合度のあのでなくてはならず，又 第 1 表の如く，高純度でなくてはならない。若しす低重 合物が含有せられている場合，分解，塩析なぞの不都合 が生ずる。

弟 2 圆に示した鍍金訊験片の底面副は，水素ガス気泡の 逃げ道がないため，界面活性㶡を添加してる，ピットは 幾分生成するが，第3 回に示す如く，面が平滑となり， 研磨は容易となつた。

份電解に传り生成する銅醋塩の不溶解性浮遊生成物が 鍍金面に付着した場合は，ピット状の凹みが生じ，これ は界面活性剤の添加によつても除去出来ない故, 濾過に 依り，予めこの生成物を濾別して抽く事が必要である。

\section{IIII結論}

ピっト発生防止のため，界面活性剤を高清 度シアン化銅浴に㳢加して央験し，次の結諭 を得た。

1) イオン型界湎活性剂收び非イオン型界 酒活性剂中の多質アルコール・エステル系の るのは敒用出来ない。

2) 重合度の比較的菖い $(p=20 \sim 50)$, 純 度のよい(有效成分 98\%以上) Polyoxyethylene lauryl alcohol ether, Polyoxyethylene sperm alcohol ether, Polyoxyethylene oleyl alcohol ether はこれ等を鍍金 液に添加してい分解せず，且つ塩析すされな い。文電解に低る分解む起らず,・ピットは容 鼠に除去出来る。

3) 添加量は，浴の表面張力を50〜30dyne $/ \mathrm{cm}\left(30^{\circ} \mathrm{C}\right)$ に低ドせしめる量で底く，多量に 加える必要はない。

4）水素ガス気泡の逃げ道のない部分のピ ットは除去出来ないが，殘留したピットは縁がなだらか

にならて研磨は谷易である。又浴中に浮遊している不溶
第3国鈸金試料片の底面部 のピットの变化 
第 3 表 界面活性剂の添加によるピット防止效綶

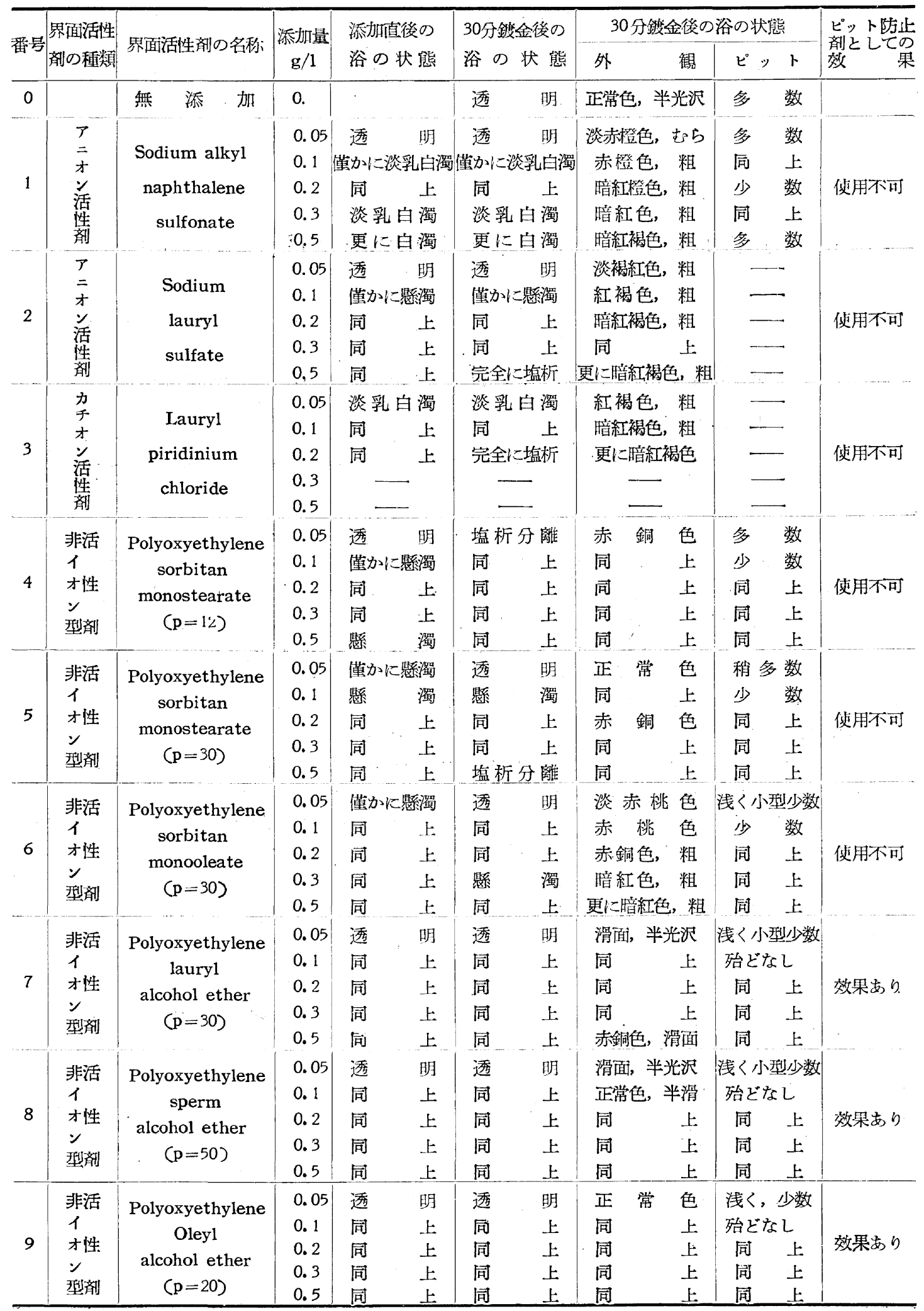


解性の銅錯塩が鍍金面に付着して生じるピット類似の凹 みは除去出来ないから，この不溶解性の銅錯塩を予め滤 別しておく事が望ましい。

終りに本研究に終始，御懇篤なる御指導を賜つた石田 武男教授 (浪大・工), 並びに佐治課長 (大工研) に括礼 申し上げ，又各界面活性風を合成，協力下ささつた花王石
劒 K.K. (和歌山工場) 宮川部長, 椪びに喜多主任に感謝 する。

向本研究に要した費用の一部を大阪府綜合技術委員会 鍍金専門委員会よりの交付金に仰いだことを付記して謝 意を表する。(1954.2.9 受理)

\title{
ラジオアイソトープによるリン酸處理被膜の研究
}

\author{
麻田宏・堀口泰裕 \\ Study on the phosphoric acid treatment for Aluminum plates \\ by radio isotope $\mathbf{P}^{32}$.
}

Hiroshi Asada, Yasuhiro Horiguchi ${ }^{*}$

\section{Synopsis}

It is reported in many works that some phosphoric compounds were formed on steel by phosphoric acid treatment, but there was scarcely any evidence so far that. the film containing phosphoric compound was fromed on the surface of $\mathrm{Al}$ alloys.

This paper concerns the testing for the film containing phosphoric compound which is formed on $\mathrm{Al}$ alloys treated with the phosphoric acid containing radio isotope $\mathrm{P}^{32}$.

$\mathrm{Al}$ alloys are treated with the phosphoric acid solution containing radio isotope $\mathrm{P}^{32}$.

(a) $\mathrm{H}_{4} \mathrm{PO}_{4}: \mathrm{CH}_{5} \mathrm{OH}=1: 3$ and (b) $\mathrm{H}_{3} \mathrm{PO}_{4}: \mathrm{CH}_{3} \mathrm{OH}: \mathrm{H}_{2} \mathrm{O}: \mathrm{CrO}_{3}=7.5: 5: 80: 7.5$.

From results, we can say that the film containing phosphoric compound does not remain, if rinsed immediately after the phosphoric acid treatment. However, if the drying is completely done after the phosphoric acid treatment, any phosphoric compound adheres strongly on the surface notwithstanding the violent operation.

\section{1. 緒 言}

本誌第 4 巻第 3 号に揭載した樣に, リン酸処理によつ て，Al 合金の表面のアラサは, 相当程度変化をらける。 鉄鋼の場合には,リン酸処理によつて表面にリン酸塩 の皮膜が形成されると云う研究も多いが，Al 合金の場 合には,リン酸処理によつて表面にリン酸塩の皮膜が出 来たと云ら確証は殆どない。

本研究は, ラジオアイソトープ $\mathrm{P}^{32}$ を使用して, 表面 にリンを含む被膜が出来るか，否かを確めたるのであ る。リン酸が如何なる化学変化をうけてる,リン酸中の $\mathrm{P}^{32}$ の原子からは， $\beta$ 線が放出されるから，金属表面上 に如何なる形ででも $\mathrm{P}^{32}$ が存在すれば， $\beta$ 線をガイガー
カウンター装置で検出することが出来る。 $\mathrm{P}^{32}$ の放射能 の強い期間であれば，極く微量な $\mathrm{P}^{32}$ の存在を確認出来 る。被膜の検出方法としては, ラジオアイットープを使 用するのが現在最良の方法である。

\section{2. 試料}

(1) ラジオアイソトープ

$\mathrm{P}^{32}$ は $\mathrm{H}_{3} \mathrm{PO}_{4}$ の弱い $\mathrm{HCl}$ 溶液として入手される。

これを $\mathrm{H}_{3} \mathrm{PO}_{4}$ で稀絼する。

(2) リン酸処理液

(a) $\mathrm{H}_{3} \mathrm{PO}_{4}: \mathrm{CH}_{3} \mathrm{OH}=1: 3^{(1)}$

(b) $\mathrm{H}_{3} \mathrm{PO}_{4}: \mathrm{CH}_{3} \mathrm{OH}: \mathrm{H}_{2} \mathrm{O}: \mathrm{CrO}_{3}=7.5: 5: 80: 7.5$

(3) 材料

* Institute of Science and Technology, University of Tokyo

* 東大理工学研究所

（1）(2) 会田長次郎，大西正次，「軽金風」, 第3 号, 1952 